\title{
Incidence of cerebrovascular disease as a comorbidity in patients with COVID-19: a meta-analysis
}

\author{
Jun Zhang ${ }^{1,2,3,{ }^{*}}$, Haili Wang ${ }^{1,4,}{ }^{*}$, Min Wei ${ }^{2,3,{ }^{*}}$, Hengzhu Zhang ${ }^{2,3}$, Boming Xia ${ }^{5}$, Xingdong Wang ${ }^{2,3}$, \\ Yunlong Pei ${ }^{1}$, Lun Dong ${ }^{2,3}$, Yuping $\mathrm{Li}^{2,3}$ \\ ${ }^{1}$ Department of Clinical Medicine, Dalian Medical University, Dalian 116044, Liaoning, China \\ ${ }^{2}$ Department of Neurosurgery, Clinical Medical College of Yangzhou University, Yangzhou 225001, Jiangsu, China \\ ${ }^{3}$ Department of Neuro Intensive Care Unit, Clinical Medical College of Yangzhou University, Yangzhou 225001, \\ Jiangsu, China \\ ${ }^{4}$ Department of Neurology, Clinical Medical College of Yangzhou University, Yangzhou 225001, Jiangsu, China \\ 5Department of Emergency Medicine, Zhejiang University School of Medicine, Hangzhou 310016, Zhejiang, China \\ *Equal contribution
}

Correspondence to: Lun Dong, Yuping Li; email: lundongu571@163.com, https://orcid.org/0000-0002-7372-331X;

liyuping2011@163.com, https://orcid.org/0000-0002-4527-2582

Keywords: COVID-19, cerebrovascular diseases, comorbidity, meta-analysis

Received: May 16, $2020 \quad$ Accepted: August 29, $2020 \quad$ Published: November 23, 2020

Copyright: (c) 2020 Zhang et al. This is an open access article distributed under the terms of the Creative Commons Attribution License (CC BY 3.0), which permits unrestricted use, distribution, and reproduction in any medium, provided the original author and source are credited.

\section{ABSTRACT}

It is essential to know whether COVID-19 patients have a history of cerebrovascular disease, as it may be predictive of prognosis and useful for allocation of limited medical resources. This meta-analysis was performed to assess the incidence of cerebrovascular disease as a comorbidity in COVID-19 patients. The PubMed, Cochrane Library, Embase, CNKI, WFSD, and VIP databases were systematically searched. The pooled analysis of relevant data was conducted using RevMan 5.3 software. The primary outcome was incidence of cerebrovascular disease as a comorbidity. Forty-seven studies involving 16,143 COVID-19 patients were included in this analysis. The incidences of a history of cerebrovascular disease and hypertension in COVID-19 patients were estimated to be $3.0 \%(95 \% \mathrm{Cl}, 2.0 \%-4.0 \%$; $\mathrm{P}<0.00001)$ and $23.0 \%(95 \% \mathrm{Cl}, 16.0 \%-29.0 \%$; $\mathrm{P}<0.00001)$, respectively. The incidence of dizziness/headache as the first symptom in COVID-19 patients was estimated to be $14.0 \%(95 \% \mathrm{Cl}, 8.0 \%-20.0 \%$; $\mathrm{P}<0.00001)$. Subgroup analyses indicated that country, sex ratio, and sample size are potential influencing factors affecting the incidences of cerebrovascular disease, hypertension, and dizziness/headache. These findings suggest that cerebrovascular disease is an underlying comorbidity among patients with COVID-19. In addition, patients experiencing dizziness/headache as the first symptom of COVID-19 should receive a neurological examination.

\section{INTRODUCTION}

COVID-19 is a serious global public-health concern that has had a startling medical, economic, educational, political, and cultural impact in a number of countries [1-4]. As of 10:00 am Central European Summer Time, 1 August 2020, there have been 17,396,943 confirmed cases of COVID-19, including 675,060 deaths, reported to the WHO (https://covid19.who.int/) [5]. Among them, the Americas, Europe, South-East Asia, Eastern Mediterranean, Africa, and Western Pacific have reported 9,320,330, 3,357,465, 2,072,194, 1,544,994, 788,448, and 312,771 cases, respectively (Figure 1A) [5]. The overall worldwide crude death rate among infected persons is about $3.88 \%$, of which the crude death rates in Europe, Americas, Western Pacific, Eastern Mediterranean, South-East Asia, and Africa are about $6.34 \%$, $3.81 \%, 2.68 \%, 2.6 \%, 2.17 \%$, and $1.72 \%$, respectively 
(Figure 1B) [5]. With the rapid increase in the number of COVID-19 patients, those with a history of cerebrovascular disease have gradually attracted the attention of clinicians and pathologists. Meta-analyses by Aggarwal et al. [6] and Wang et al. [7] showed that underlying cerebrovascular disease is related to increased disease severity in COVID-19 patients. It is therefore important to identify a history of cerebrovascular disease in COVID-19 patients, which will help to predict their prognosis and support more effective allocation of limited medical resources. Many studies have reported the incidences of cerebrovascular disease as a comorbidity in patients with COVID-19 [8-54]. However, there are moderate differences among these studies. In addition, some are single-center studies and have an insufficient sample size, low population representativeness, and limited universality of conclusions. For those reasons, this meta-analysis was performed to estimate the incidence of a history of cerebrovascular disease among patients with COVID-19.

\section{RESULTS}

\section{Search and quality assessment results}

Using the retrieval strategy summarized in the Methods, a total of 7,190 related studies were evaluated, and 1825 papers remained after 5365 duplicate articles were excluded. After reading the titles and abstracts, 1744 studies that did not meet the inclusion criteria were excluded. After evaluating of the remaining 81 articles applicability by reading the full text, an additional 34 were ruled out based on the exclusion criteria. Ultimately, 47 studies [8-54], including 19 Chinese
[8-26] and 28 English language [27-54] studies were included. The PRISMA flow diagram of the literature screening is shown in Figure 2. In addition, the quality assessment and baseline characteristics of the included articles are depicted in Table 1. The studies mainly reported the clinical characteristics of patients with COVID-19, incidences of underlying diseases, and prognoses. The participants in these studies mainly came from China, the United States, the United Kingdom, and Italy. The sample size distribution among these studies was roughly 21 to 5,700. Moreover, there were $3,14,10$, 7,7 , and 5 studies with quality scores of $3,4,5,6,7$, and 8 , respectively. Thus, the literature included in our metaanalysis was of relatively high quality.

\section{Meta-analysis findings}

\section{Primary outcome}

Incidence of cerebrovascular disease as a comorbidity in patients with COVID-19

There were 18 studies [12-14, 17, 25, 27, 30, 32, 35, 36, 39-42, 44-47] reporting incidences of a history of cerebrovascular diseases among patients with COVID19. We used a ratio difference (RD) as the effect size, and then applied generic inverse variance to calculate the pooled effect size. The pooled findings are shown in Figure 3 . The heterogeneity test demonstrated moderate to significant heterogeneity among the studies $\left(\mathrm{Chi}^{2}=76.06, \mathrm{I}^{2}=79 \%, \mathrm{P}<0.00001\right)$, so the random-effects model was applied. The pooled incidence was 3.0\% $(95 \% \mathrm{CI}=2.0 \%-4.0 \%, \mathrm{P}<0.00001)$. The pooled finding indicated that $3.0 \%$ of COVID-19 patients had underlying cerebrovascular disease.
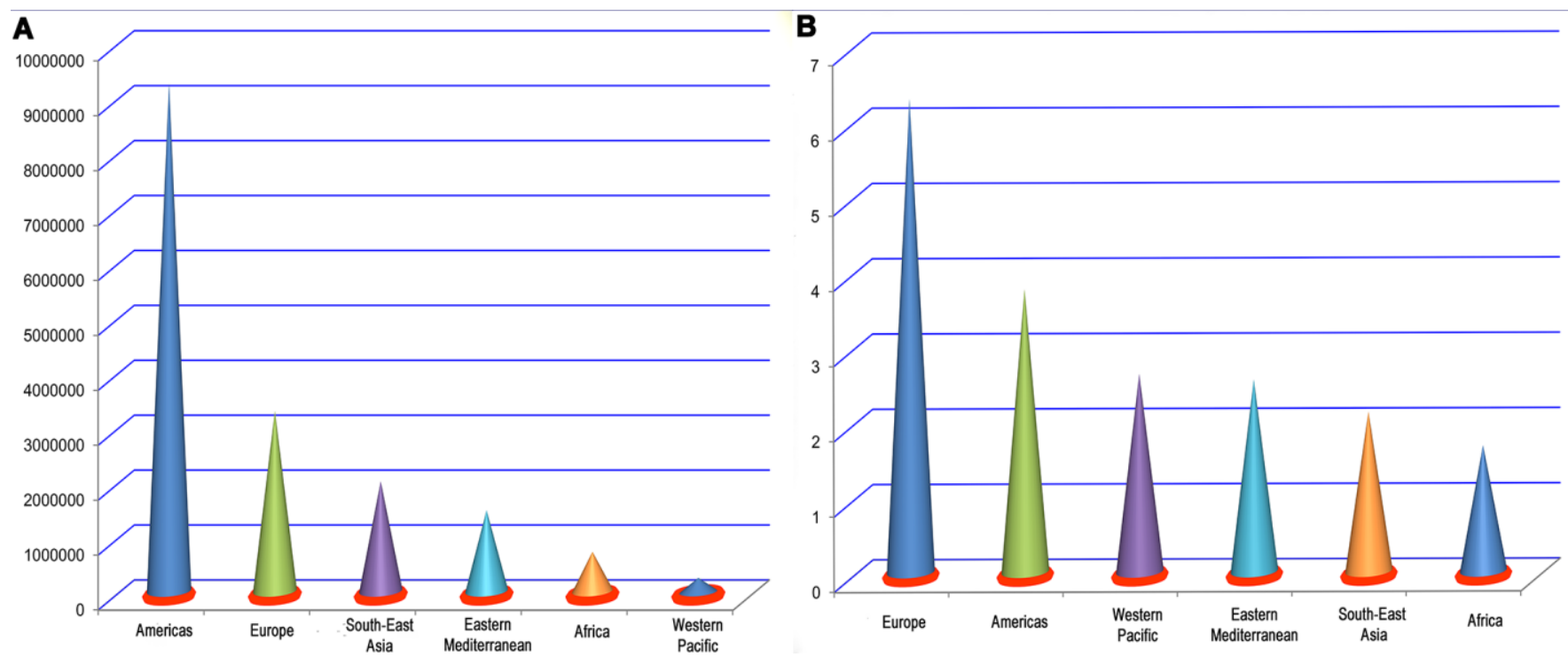

Figure 1. Number of infections (A) and crude death rate (\%) (B) by region. 


\section{Secondary outcomes}

Incidence of hypertension as a comorbidity in patients with COVID-19

Forty one [8-18, 21-26, 29-31, 33-46, 48-54] articles presented incidences of a history of hypertension in patients with COVID-19. Using RD as the effect size, we applied generic inverse variance to calculate the pooled effect size (Figure 4). We found that there was significant heterogeneity among the studies $\left(\mathrm{Chi}^{2}=3682.38, \mathrm{I}^{2}=99 \%\right.$, $\mathrm{P}<0.00001$ ), so the random-effects model was used. The pooled incidence was $23.0 \%$ (95\% CI $=16.0 \%-29.0 \%$, $\mathrm{P}<0.00001$ ), suggesting $23.0 \%$ of COVID-19 patients had a history of hypertension.

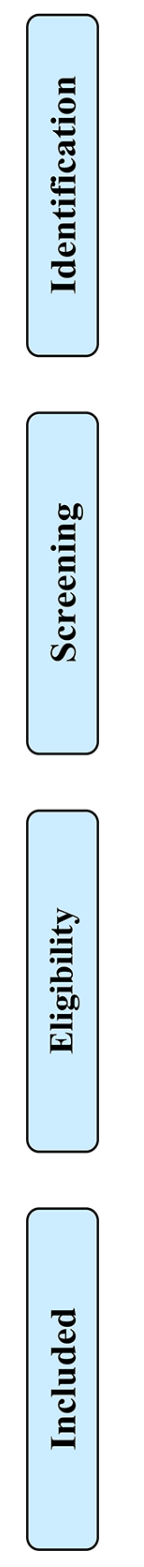

Incidence of dizziness or headache in patients with COVID-19

There were 36 papers [8-16, 18-21, 24, 26-28, 31, 32, $35-38,40,48,51-54]$ reporting incidences of dizziness or headache (first symptom) in patients with COVID19. Again using the $\mathrm{RD}$ as the effect size, generic inverse variance was applied to calculate the pooled effect size (Figure 5). The heterogeneity test indicated obvious heterogeneity among the studies $\left(\mathrm{Chi}^{2}=2467.9\right.$, $\mathrm{I}^{2}=99 \%, \mathrm{P}<0.00001$ ), so the random-effects model was applied. The pooled incidence was $14.0 \%$ (95\% CI $=8.0 \%-20.0 \%, \mathrm{P}<0.00001)$. Thus, $14.0 \%$ of COVID-19 patients presented with dizziness or headache as their first symptom.

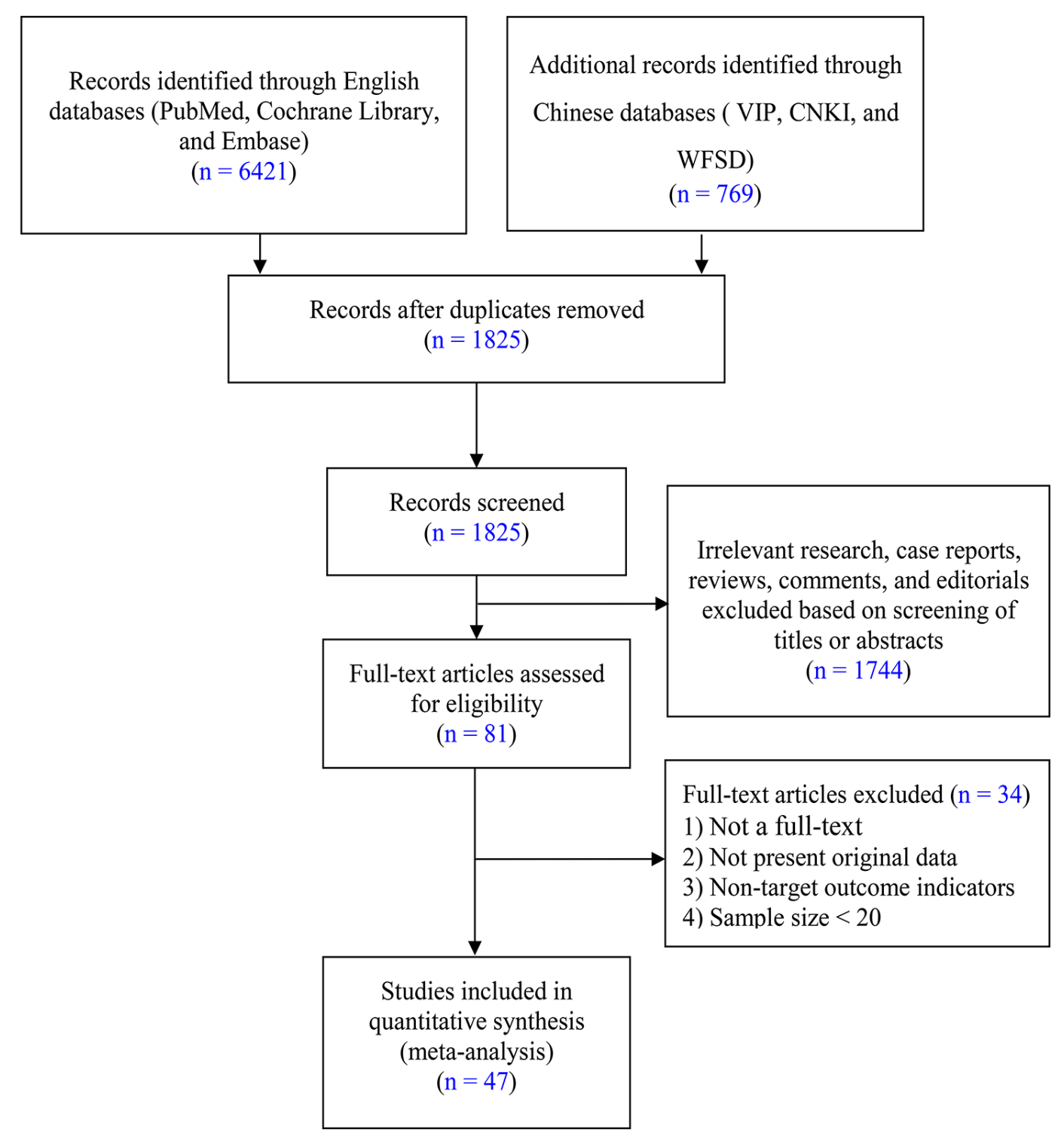

Figure 2. PRISMA flow diagram showing selection of the literature for this meta-analysis. 
Table 1. Quality assessment and baseline characteristics of the included studies.

\begin{tabular}{|c|c|c|c|c|c|c|c|c|c|}
\hline Study and year & $\begin{array}{c}\text { Quality } \\
\text { assessment }\end{array}$ & Country & $\begin{array}{c}\text { Publishing } \\
\text { language }\end{array}$ & $\begin{array}{l}\text { Sample } \\
\text { size }\end{array}$ & Males/Females & Age & $\begin{array}{c}\text { Cerebrovascular } \\
\text { disease, }(\%)\end{array}$ & $\begin{array}{c}\text { Hypertension, } \\
(\%)\end{array}$ & $\begin{array}{c}\text { Dizziness } \\
\text { or } \\
\text { headache, } \\
(\%)\end{array}$ \\
\hline Yuan,2020[9] & 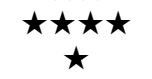 & China & Chinese & 223 & $106 / 117$ & $46.5 \pm 16.1$ & - & $25,(11.2)$ & $11,(4.9)$ \\
\hline Wang, $2020^{\mathrm{a}}[10]$ & $\star \star \star \star \star$ & China & Chinese & 32 & $16 / 16$ & - & - & $5,(15.6)$ & $1,(3.1)$ \\
\hline Wang,2020 $[13]$ & $\star \star \star \star \star$ & China & Chinese & 96 & $46 / 50$ & - & $3,(3.1)$ & $50,(52.1)$ & $2,(2.1)$ \\
\hline Lei,2020[14] & $\star \star \star \star \star$ & China & Chinese & 51 & $25 / 16$ & $26-82$ & $1,(1.96)$ & $9,(17.6)$ & $1,(1.96)$ \\
\hline Dong,2020[15] & $\begin{array}{c}\star \star \star \star \\
\star \star\end{array}$ & China & Chinese & 27 & $13 / 14$ & $23-68$ & - & $4,(14.8)$ & $4,(14.8)$ \\
\hline Zhong,2020[19] & $\star \star \star \star \star$ & China & Chinese & 62 & $40 / 22$ & $28-77$ & - & - & $2,(3.2)$ \\
\hline $\mathrm{Xu}, 2020^{\mathrm{a}}[20]$ & $\begin{array}{c}\star \star \star \star \\
\star\end{array}$ & China & Chinese & 155 & $87 / 68$ & $41.99 \pm 15.40$ & - & - & $5,(3.2)$ \\
\hline Gong,2020[21] & $\begin{array}{c}\star \star \star \star \star ~ \\
\star \star \star\end{array}$ & China & Chinese & 80 & $45 / 35$ & $18-82$ & - & $8,(10.0)$ & $10,(8.0)$ \\
\hline Chen, $2020^{\mathrm{a}}[22]$ & $\begin{array}{c}\star \star \star \star \\
\star\end{array}$ & China & Chinese & 67 & $20 / 47$ & $11-85$ & - & $12,(17.9)$ & - \\
\hline $\mathrm{Lu}, 2020[23]$ & $\begin{array}{c}\star \star \star \star \\
\star\end{array}$ & China & Chinese & 50 & $28 / 22$ & $50.4 \pm 16.8$ & - & $8,(16)$ & - \\
\hline Huang, $2020^{\mathrm{a}}[24]$ & $\star \star \star \star \star$ & China & Chinese & 35 & $19 / 16$ & $12-74$ & - & $1,(2.9)$ & $3,(8.6)$ \\
\hline Liang, $2020^{\mathrm{a}}[25]$ & $\star \star \star$ & China & Chinese & 28 & $16 / 12$ & $24-87$ & $1,(3.6)$ & $9,(32.1)$ & - \\
\hline Zhuang,2020[26] & $\star \star \star \star \star$ & China & Chinese & 26 & $18 / 8$ & $3-79$ & - & $4,(15.4)$ & $6,(23.1)$ \\
\hline Yang,2020[27] & $\begin{array}{c}\star \star \star \star \star ~ \\
\star \star \star\end{array}$ & China & English & 149 & $81 / 68$ & $45.11 \pm 13.35$ & $0,(0)$ & - & $13,(8.7)$ \\
\hline Chen, $2020^{\mathrm{c}}[32]$ & $\begin{array}{c}\star \star \star \star \\
\star \star \star\end{array}$ & China & English & 99 & $67 / 32$ & $55.5 \pm 13.1$ & $1,(1.0)$ & - & $8,(8.1)$ \\
\hline Zhou, 2020[33] & $\begin{array}{l}\star \star \star \star \\
\star \star \star \star\end{array}$ & China & English & 191 & $119 / 72$ & $56.0 \pm 15.6$ & - & $58,(30.3)$ & - \\
\hline Goyal,2020[34] & $\star \star \star \star \star$ & America & English & 393 & $238 / 155$ & $62.2 \pm 18.6$ & - & $197,(50.1)$ & - \\
\hline Guan,2020[35] & $\begin{array}{l}\star \star \star \star \\
\star \star \star \star\end{array}$ & China & English & 1099 & $640 / 459$ & $47.0 \pm 17.0$ & $15,(1.4)$ & $165,(15.0)$ & $150,(13.6)$ \\
\hline Chen, $2020^{\mathrm{d}}[36]$ & $\begin{array}{c}\star \star \star \star \star ~ \\
\star \star \star\end{array}$ & China & English & 203 & $108 / 95$ & $20-91$ & $43,(21.2)$ & $9,(4.4)$ & $14,(6.9)$ \\
\hline Qian,2020[37] & $\star \star \star \star \star$ & China & English & 91 & $37 / 54$ & $5-96$ & - & $15,(16.5)$ & $7,(7.7)$ \\
\hline Liu, $2020^{\mathrm{b}}[38]$ & $\begin{array}{c}\star \star \star \star \\
\star \star \star\end{array}$ & China & English & 137 & $61 / 76$ & $20-83$ & - & $13,(9.5)$ & $13,(9.5)$ \\
\hline Zhang,2020 ${ }^{\mathrm{b}}[39]$ & $\begin{array}{c}\star \star \star \star \\
\star\end{array}$ & China & English & 140 & $71 / 69$ & $25-87$ & $3,(2.1)$ & $42,(30)$ & - \\
\hline Zhou, 2020 $[40]$ & $\begin{array}{c}\star \star \star \star \star ~ \\
\star \star\end{array}$ & China & English & 21 & $13 / 8$ & $66.1 \pm 13.9$ & $3,(14.3)$ & $10,(47.6)$ & $0,(0)$ \\
\hline $\mathrm{Xu}, 2020^{\mathrm{b}}[41]$ & $\begin{array}{c}\star \star \star \star \star \\
\star \star \star\end{array}$ & China & English & 62 & $35 / 27$ & $41.0 \pm 15.6$ & $1,(1.6)$ & $5,(8.1)$ & $21,(33.9)$ \\
\hline Chen, $2020^{\mathrm{e}}[42]$ & $\begin{array}{c}\star \star \star \star \star ~ \\
\star \star \star\end{array}$ & China & English & 274 & $171 / 103$ & $62.0 \pm 19.3$ & $4,(1.5)$ & $93,(33.9)$ & $52,(19.0)$ \\
\hline Zheng,2020 ${ }^{\mathrm{a}}[43]$ & 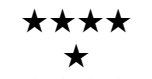 & China & English & 96 & $58 / 38$ & $55.0 \pm 15.2$ & - & $35,(36.5)$ & $11,(11.5)$ \\
\hline Liang, 2020 [4 [44] & $\star \star \star \star \star$ & China & English & 1590 & $904 / 674$ & $48.9 \pm 16.3$ & $30,(1.9)$ & $269,(16.9)$ & $205,(15.4)$ \\
\hline
\end{tabular}




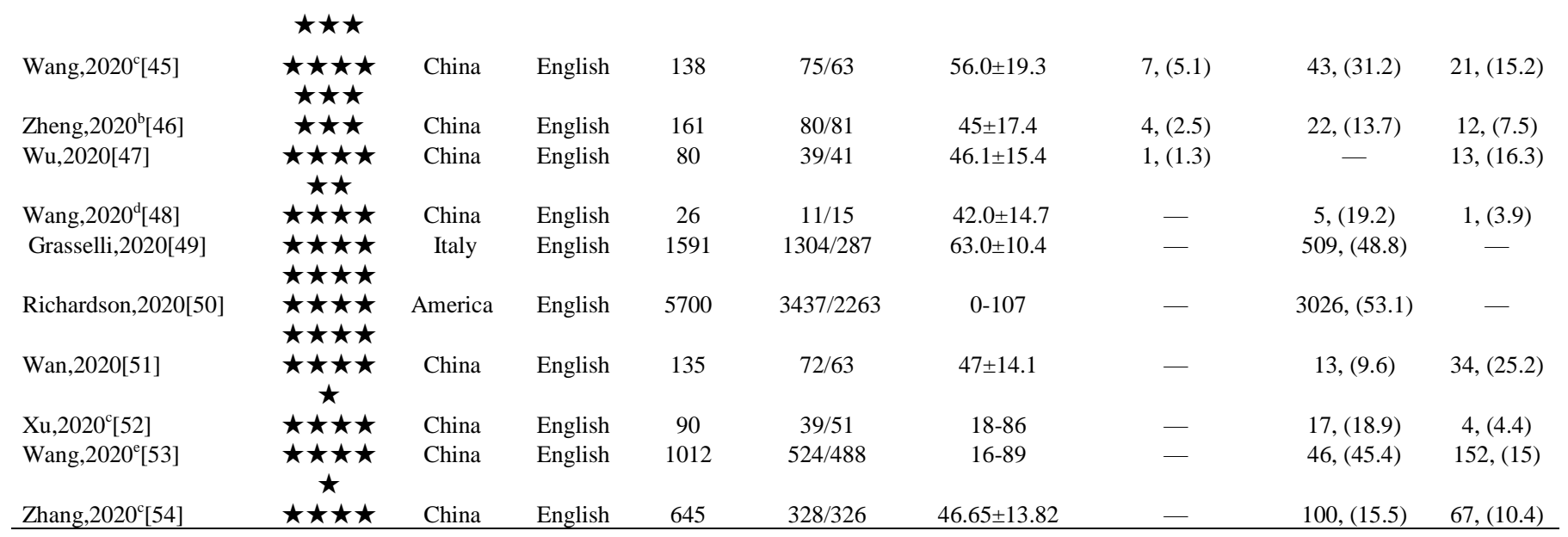

\section{Subgroup analysis}

Subgroup analysis was applied to investigate the potential impact on constituent ratios of cerebrovascular disease, hypertension, and dizziness or headache of country (China and other countries), sex ratio (males/females $<1$ and $\geq 1$ ), and sample size $(<100$ and $>100)$. Results of the subgroup analyses are shown in Table 2 . The findings suggest that country, sex ratio, and sample size are all potential influencing factors and heterogeneity sources for the constituent ratios for cerebrovascular disease, hypertension, and dizziness or headache.

\section{Sensitivity analysis and publication bias}

We evaluated the effect of each study on the pooled constituent ratio value by sequentially removing single studies. The results revealed no obvious change in stability, which validated the rationality and reliability of our meta-analysis. The funnel plot is depicted in Figure 6. Publication bias was rated as slight to moderate based on visualization of the funnel plot. We therefore cautiously suggest that the results of this study are relatively stable and reliable.

\begin{tabular}{|c|c|c|c|c|c|c|c|c|}
\hline Study or Subgroup & Risk Difference & SE & Weight & $\begin{array}{l}\text { Risk Difference } \\
\text { IV. Random, } 95 \% \mathrm{CI}\end{array}$ & \multicolumn{3}{|c|}{$\begin{array}{c}\text { Risk Difference } \\
\text { IV. Random, } 95 \% \mathrm{Cl}\end{array}$} & \\
\hline Chen,2020c & 0.01 & 0.01 & $8.0 \%$ & $0.01[-0.01,0.03]$ & & & $F$ & \\
\hline Chen,2020d & 0.212 & 0.029 & $2.6 \%$ & $0.21[0.16,0.27]$ & & & & \\
\hline Chen,2020e & 0.015 & 0.007 & $9.4 \%$ & $0.01[0.00,0.03]$ & & & - & \\
\hline Guan,2020 & 0.014 & 0.004 & $10.5 \%$ & $0.01[0.01,0.02]$ & & & $=$ & \\
\hline Lei,2020 & 0.0196 & 0.019 & $4.6 \%$ & $0.02[-0.02,0.06]$ & & & & \\
\hline Liang,2020a & 0.036 & 0.035 & $1.9 \%$ & $0.04[-0.03,0.10]$ & & & & \\
\hline Liang,2020b & 0.019 & 0.003 & $10.8 \%$ & $0.02[0.01,0.02]$ & & & $=$ & \\
\hline Lovell,2020 & 0.119 & 0.032 & $2.2 \%$ & $0.12[0.06,0.18]$ & & & & \\
\hline Tong,2020 & 0.0039 & 0.0039 & $10.6 \%$ & $0.00[-0.00,0.01]$ & & & $\mathbf{r}$ & \\
\hline Wang,2020b & 0.031 & 0.018 & $4.9 \%$ & $0.03[-0.00,0.07]$ & & & & \\
\hline Wang,2020c & 0.051 & 0.019 & $4.6 \%$ & $0.05[0.01,0.09]$ & & & & \\
\hline $\mathrm{Wu}, 2020$ & 0.013 & 0.013 & $6.7 \%$ & $0.01[-0.01,0.04]$ & & & F & \\
\hline$X u, 2020 b$ & 0.016 & 0.016 & $5.6 \%$ & $0.02[-0.02,0.05]$ & & & & \\
\hline Yang,2020 & 0 & 0 & & Not estimable & & & & \\
\hline Zhang,2020b & 0.021 & 0.012 & $7.1 \%$ & $0.02[-0.00,0.04]$ & & & 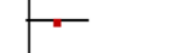 & \\
\hline Zheng,2020b & 0.025 & 0.012 & $7.1 \%$ & $0.03[0.00,0.05]$ & & & 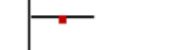 & \\
\hline Zhou,2020b & 0.143 & 0.076 & $0.5 \%$ & $0.14[-0.01,0.29]$ & & & & \\
\hline Zuo,2020 & 0.04 & 0.028 & $2.7 \%$ & $0.04[-0.01,0.09]$ & & & & \\
\hline Total $(95 \% \mathrm{Cl})$ & & & $100.0 \%$ & $0.03[0.02,0.04]$ & & & 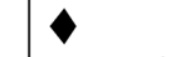 & \\
\hline \multicolumn{5}{|c|}{ Heterogeneity: $\mathrm{Tau}^{2}=0.00 ; \mathrm{Chi}^{2}=76.06, \mathrm{df}=16(P<0.00001) ; \mathrm{I}^{2}=79 \%$} & -0.2 & -0.1 & Cerebro & disea \\
\hline
\end{tabular}

Figure 3. Forest plot showing the incidence of cerebrovascular disease as a comorbidity in patients with COVID-19. 


\section{DISCUSSION}

This meta-analysis of pooling findings demonstrated that $3 \%$ of COVID-19 patients have a history of cerebrovascular disease and $23.0 \%$ have a history of hypertension. It is also worth noting that $14.0 \%$ of patients have neurological symptoms (dizziness or headache) as the first symptom of COVID-19.
A meta-analysis by Zhu et al. [55], involving 3,062 patients with COVID-19, showed that fever, fatigue, cough and expectoration are the most common clinical symptoms. Like us, however, they reported that dizziness or headache symptoms also occur (Zhu et al. 15.4\% vs. the present meta-analysis: $14.0 \%$ ). To effectively allocate medical resources, we need to attach great importance to early neurological symptoms (dizziness, headache,
Risk Difference

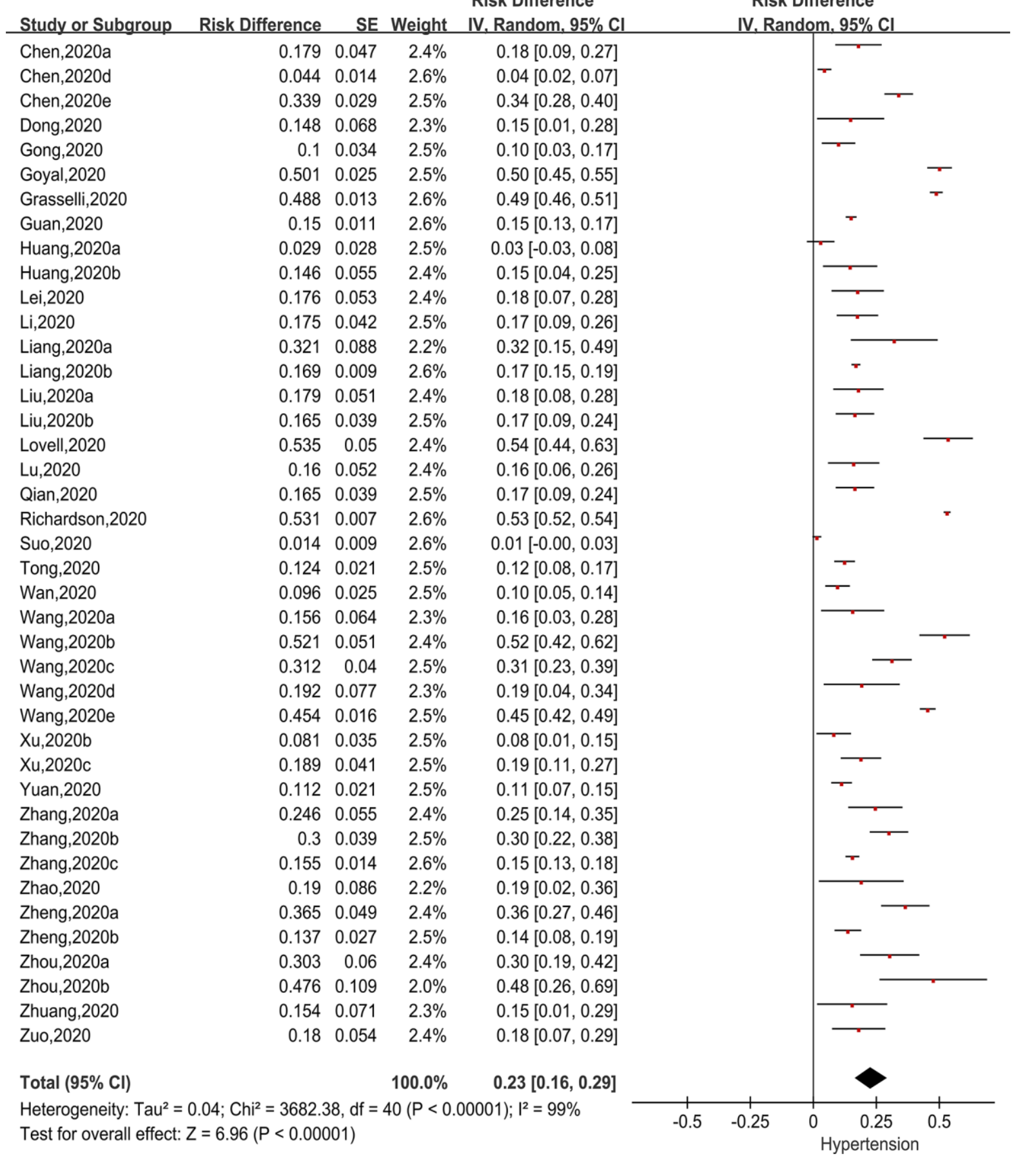

Risk Difference IV. Random, $95 \% \mathrm{Cl}$

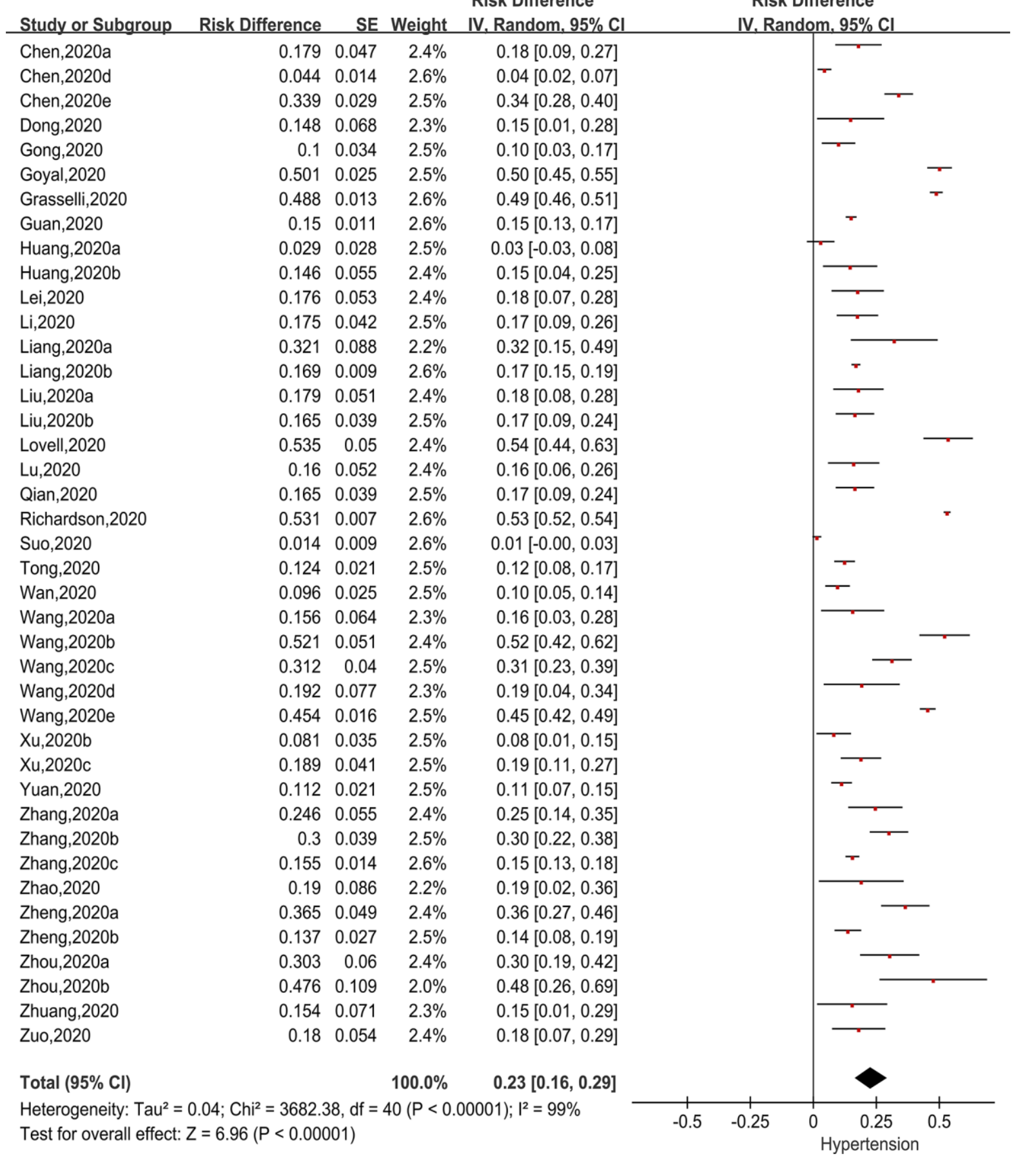

the first symptom of COVID-19.

Figure 4. Forest plot showing the incidence of hypertension as a comorbidity in patients with COVID-19. 
seizures etc.) in COVID-19 patients because they may not be purely related to COVID-19, but may be early signs of cerebrovascular disease. Moreover, our results indicate that about 3\% COVID-19 patients had a history of cerebrovascular disease. It is therefore necessary to record early neurological symptoms and signs in COVID-19 patients. This may involve not only patient shunting and altered medical resource allocation, but also adjustment of the treatment protocol.
Angiotensin-converting enzyme 2 (ACE2) receptors are reported to be a key gateway through which viruses invade human organs or tissues [56]. This makes organs and tissues enriched in ACE2 receptors susceptible to attack by viruses. Although the lungs are ground zero, SARS-CoV-2, the virus causing COVID-19, can also infect other organs, including the brain, blood vessels, heart, testicles, kidneys, and gut [56]. When SARS-CoV-2 invades the body, its spike glycoprotein receptor-binding

\begin{tabular}{|c|c|c|c|c|c|c|c|}
\hline Study or Subgroup & Risk Difference & SE & Weight & $\begin{array}{l}\text { Risk Difference } \\
\text { IV. Random, } 95 \% \mathrm{Cl}\end{array}$ & $\begin{array}{r}\text { Risk } \\
\text { IV. Ran }\end{array}$ & $\begin{array}{l}\text { Difference } \\
\text { dom. } 95 \% \mathrm{Cl}\end{array}$ & \\
\hline Chen,2020b & 0.087 & 0.023 & $2.9 \%$ & $0.09[0.04,0.13]$ & & 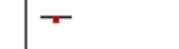 & \\
\hline Chen,2020c & 0.079 & 0.044 & $2.8 \%$ & $0.08[-0.01,0.17]$ & & 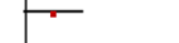 & \\
\hline Chen,2020d & 0.069 & 0.018 & $3.0 \%$ & $0.07[0.03,0.10]$ & & - & \\
\hline Chen,2020e & 0.19 & 0.024 & $2.9 \%$ & $0.19[0.14,0.24]$ & & - & \\
\hline Dong,2020 & 0.148 & 0.068 & $2.6 \%$ & $0.15[0.01,0.28]$ & & & \\
\hline Gong,2020 & 0.8 & 0.014 & $3.0 \%$ & $0.80[0.77,0.83]$ & & & T \\
\hline Guan,2020 & 0.136 & 0.01 & $3.0 \%$ & $0.14[0.12,0.16]$ & & $\boldsymbol{T}$ & \\
\hline Huang,2020a & 0.086 & 0.047 & $2.8 \%$ & $0.09[-0.01,0.18]$ & & 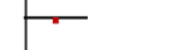 & \\
\hline Huang,2020b & 0.079 & 0.044 & $2.8 \%$ & $0.08[-0.01,0.17]$ & & 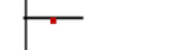 & \\
\hline Lei,2020 & 0.148 & 0.045 & $2.8 \%$ & $0.15[0.06,0.24]$ & & $\longrightarrow$ & \\
\hline $\mathrm{Li}, 2020$ & 0.15 & 0.04 & $2.8 \%$ & $0.15[0.07,0.23]$ & & $\leftarrow$ & \\
\hline Liang,2020b & 0.154 & 0.01 & $3.0 \%$ & $0.15[0.13,0.17]$ & & $r$ & \\
\hline Liu,2020b & 0.077 & 0.028 & $2.9 \%$ & $0.08[0.02,0.13]$ & & - & \\
\hline Qian,2020 & 0.077 & 0.028 & $2.9 \%$ & $0.08[0.02,0.13]$ & & - & \\
\hline Suo,2020 & 0.094 & 0.022 & $2.9 \%$ & $0.09[0.05,0.14]$ & & - & \\
\hline Wan,2020 & 0.252 & 0.037 & $2.9 \%$ & $0.25[0.18,0.32]$ & & & \\
\hline Wang,2020a & 0.031 & 0.031 & $2.9 \%$ & $0.03[-0.03,0.09]$ & & - & \\
\hline Wang,2020b & 0.148 & 0.045 & $2.8 \%$ & $0.15[0.06,0.24]$ & & 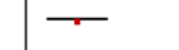 & \\
\hline Wang,2020c & 0.152 & 0.031 & $2.9 \%$ & $0.15[0.09,0.21]$ & & $\leftarrow$ & \\
\hline Wang,2020d & 0.039 & 0.038 & $2.9 \%$ & $0.04[-0.04,0.11]$ & & - & \\
\hline Wang,2020e & 0.15 & 0.011 & $3.0 \%$ & $0.15[0.13,0.17]$ & & $\pi$ & \\
\hline Wu,2020 & 0.163 & 0.041 & $2.8 \%$ & $0.16[0.08,0.24]$ & & $\longrightarrow$ & \\
\hline $\mathrm{Xu}, 2020 \mathrm{a}$ & 0.032 & 0.014 & $3.0 \%$ & $0.03[0.00,0.06]$ & & $F$ & \\
\hline$X u, 2020 b$ & 0.339 & 0.06 & $2.7 \%$ & $0.34[0.22,0.46]$ & & & \\
\hline$X u, 2020 c$ & 0.044 & 0.022 & $2.9 \%$ & $0.04[0.00,0.09]$ & & - & \\
\hline Yang,2020 & 0.087 & 0.023 & $2.9 \%$ & $0.09[0.04,0.13]$ & & - & \\
\hline Yuan,2020 & 0.049 & 0.014 & $3.0 \%$ & $0.05[0.02,0.08]$ & & $=$ & \\
\hline Zhang,2020a & 0.148 & 0.045 & $2.8 \%$ & $0.15[0.06,0.24]$ & & $\cdots$ & \\
\hline Zhang,2020c & 0.104 & 0.012 & $3.0 \%$ & $0.10[0.08,0.13]$ & & r & \\
\hline Zhao,2020 & 0.19 & 0.086 & $2.4 \%$ & $0.19[0.02,0.36]$ & & & \\
\hline Zheng,2020a & 0.115 & 0.033 & $2.9 \%$ & $0.12[0.05,0.18]$ & & - & \\
\hline Zheng,2020b & 0.075 & 0.021 & $2.9 \%$ & $0.07[0.03,0.12]$ & & - & \\
\hline Zhong,2020 & 0.032 & 0.022 & $2.9 \%$ & $0.03[-0.01,0.08]$ & & - & \\
\hline Zhou,2020b & 0 & 0 & & Not estimable & & & \\
\hline Zhuang,2020 & 0.231 & 0.083 & $2.5 \%$ & $0.23[0.07,0.39]$ & & & \\
\hline Zuo,2020 & 0.148 & 0.045 & $2.8 \%$ & $0.15[0.06,0.24]$ & & 7 & \\
\hline Total $(95 \% \mathrm{Cl})$ & & & $100.0 \%$ & $0.14[0.08,0.20]$ & & & \\
\hline \multicolumn{5}{|c|}{$\begin{array}{l}\text { Heterogeneity: } \mathrm{Tau}^{2}=0.03 ; \mathrm{Chi}^{2}=2467.90, \mathrm{df}=34(P<0.00001) ; \mathrm{I}^{2}=99 \% \\
\text { Test for overall effect: } Z=4.46(P<0.00001)\end{array}$} & $-0.5-c$ & $\begin{array}{lr}0 & 0.25 \\
0\end{array}$ & 0.5 \\
\hline
\end{tabular}

Figure 5. Forest plot showing the proportion of patients with dizziness or headache. 
Table 2. Subgroup analysis of the impact of country, sex ratio, and sample size on the pooled findings.

\begin{tabular}{|c|c|c|c|c|c|c|}
\hline Terms & Subgroups & Number & Ratio, (\%) & 95\% CI & $\mathbf{I}^{2},(\%)$ & $\mathbf{P}$ \\
\hline \multirow[t]{9}{*}{ CVD } & Country & & & & & \\
\hline & China & 17 & 0.02 & $0.01-0.03$ & 77 & $<0.00001$ \\
\hline & British & 1 & 0.12 & $0.06-0.18$ & - & 0.0002 \\
\hline & Sex ratio (Males/Females) & & & & & \\
\hline & $<1$ & 4 & 0.02 & $0.01-0.04$ & 0 & 0.002 \\
\hline & $\geq 1$ & 14 & 0.03 & $0.02-0.04$ & 84 & $<0.00001$ \\
\hline & Sämple size & & & & & \\
\hline & $<100$ & 8 & 0.02 & $0.01-0.03$ & 0 & 0.003 \\
\hline & $>100$ & 10 & 0.03 & $0.02-0.05$ & 89 & $<0.0001$ \\
\hline \multirow[t]{9}{*}{ HTN } & Country & & & & & \\
\hline & China & 37 & 0.19 & $0.15-0.23$ & 96 & $<0.00001$ \\
\hline & Other countries & 4 & 0.51 & $0.48-0.54$ & 67 & $<0.00001$ \\
\hline & Sex ratio (Males/Females) & & & & & \\
\hline & $<1$ & 11 & 0.18 & $0.10-0.25$ & 94 & $<0.00001$ \\
\hline & $\geq 1$ & 30 & 0.25 & $0.17-0.32$ & 99 & $<0.00001$ \\
\hline & Sämple size & & & & & \\
\hline & $<100$ & 22 & 0.20 & $0.15-0.25$ & 81 & $<0.00001$ \\
\hline & $>100$ & 19 & 0.26 & $0.16-0.36$ & 99 & $<0.00001$ \\
\hline \multirow[t]{9}{*}{$\mathrm{D}$ or $\mathrm{H}$} & Country & & & & & \\
\hline & China & 36 & 0.14 & $0.08-0.20$ & 99 & $<0.00001$ \\
\hline & Other countries & - & - & - & - & - \\
\hline & Sex ratio (Males/Females) & & & & & \\
\hline & $<1$ & 11 & 0.08 & $0.06-0.10$ & 45 & $<0.00001$ \\
\hline & $\geq 1$ & 25 & 0.16 & $0.08-0.24$ & 99 & 0.0001 \\
\hline & Sample size & & & & & \\
\hline & $<100$ & 21 & 0.16 & $0.01-0.31$ & 99 & 0.04 \\
\hline & $>100$ & 15 & 0.11 & $0.09-0.14$ & 89 & $<0.00001$ \\
\hline
\end{tabular}

(CVD: cerebrovascular disease; HTN: hypertension; D or H: dizziness or headache).

domain binds to ACE2 receptors, which may cause down-regulation of ACE2 expression [57]. The accompanying vasoconstriction (increased blood pressure) may become a risk factor for cerebrovascular disease. An observational study (single center and retrospective) by $\mathrm{Li}$ et al. [58] found that among 211 COVID-19 patients, 6\% developed cerebrovascular disease.

As far as we know, the incidence of cerebrovascular disease in COVID-19 patients with underlying hypertension has not yet been reported (about 23\% hypertension patients need to be closely watched). It was recently reported, however, that blood pressure variability or threshold hypertension was associated with a poor prognosis in patients with cerebrovascular disease [59]. This prompted us to ask the question, do COVID-19 patients with cerebrovascular disease comorbidity have a poorer prognosis than those without it? To answer that question, we systematically searched the PubMed database and found that a meta-analysis demonstrated that patients with a history of cerebrovascular disease have a 2.5-fold greater likelihood of severe COVID-19 illness [6]. On the other hand, the relationship between blood pressure variability and the prognosis of comorbid patients
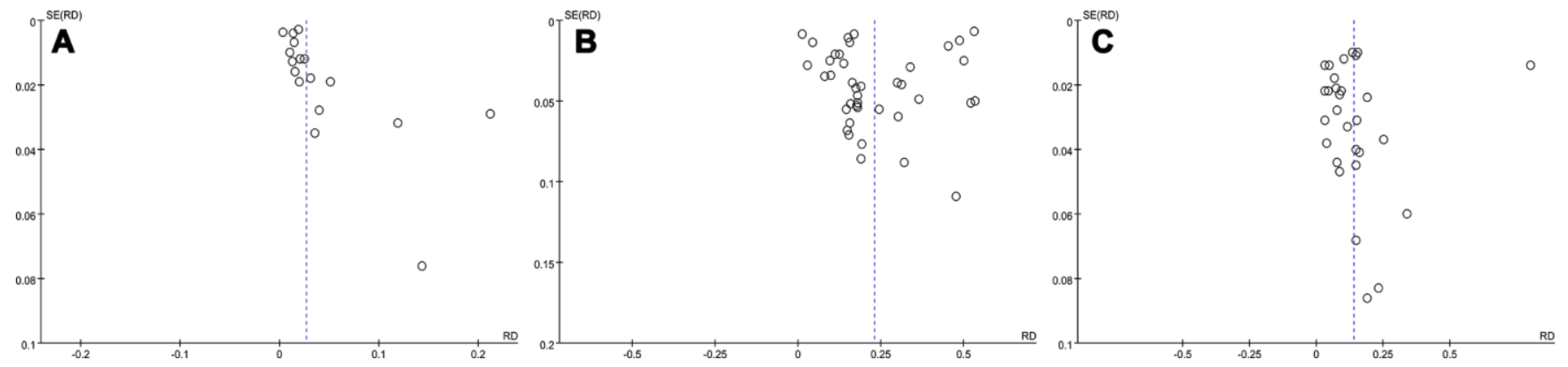

Figure 6. Funnel plot for cerebrovascular disease (A), hypertension (B), and dizziness or headache (C). 
(cerebrovascular disease and COVID-19) remains unclear.

Subgroup analyses demonstrated that country (China and other countries), sex ratio (males/females $<1$ and $\geq 1)$, and sample size $(<100$ and $>100)$ are potential influencing factors and heterogeneity sources affecting constituent ratios for cerebrovascular disease, hypertension, and dizziness or headache. It is particularly noteworthy that the constituent ratios for cerebrovascular disease and hypertension may differ among COVID-19 patients from different race groups. In addition, subgroup analysis of sex ratios suggests that men are more likely to have comorbidities (cerebrovascular disease and hypertension) and neurological symptoms (dizziness or headache). This implies that men may be more susceptible to SARS-CoV-2 infection and suggests investigation of possible detrimental effects of androgen and/or beneficial effects of estrogen may be warranted. Subgroup analysis of sample size may be less helpful in explaining the composition ratio and or rate, but it may be the source of heterogeneity between studies.

This study has several limitations. First, although 47 studies were included, the heterogeneity among studies was obvious, which may make the statistical efficiency insufficient. Second, the patients included in the analysis are mainly Chinese, which may bring challenges to the conclusions drawn. Third, several included studies did not clearly state their inclusion and exclusion criteria, disease course, or disease severity (lower quality assessment results). Fourth, due to the inclusion of data limitations, subgroup analysis was not comprehensive with regard to age, race, disease severity, and disease stage.

\section{CONCLUSIONS}

Despite the limitations of this study, which may have influenced the results, the authors conclude that cerebrovascular disease and hypertension are comorbidities among patients with COVID-19. In addition, patients reporting dizziness and headache as the first symptoms of COVID-19 should be administered neurological examinations. The difference in the degree to which men and women tolerate SARS-CoV-2 may provide a clue to the prevention and treatment of COVID-19.

\section{MATERIALS AND METHODS}

This meta-analysis follows the PRISMA (Preferred Reporting Items for Systematic Reviews and MetaAnalyses) guidelines [60].

\section{Search strategy}

To identify eligible studies, the main search was conducted in the PubMed, Cochrane Library, Embase, CNKI, WFSD, and VIP electronic databases for studies published between December 1, 2019 and April 26, 2020. The keywords used were 2019nCoV/Coronavirus/COVID-19/SARS CoV-2/2019 novel coronavirus infection/coronavirus disease 2019/2019 novel coronavirus disease/coronavirus 2019/COVID-2019 and features/characteristics. Specific retrieval strategies were adjusted to accommodate the different databases. The procedure was concluded by: 1) the perusal of the reference sections of all relevant studies; 2) a manual search of key journals and abstracts from the major databases in the field of COVID-19; and 3) contacting experts to try to acquire unpublished data. The main search was completed independently by investigators. Any discrepancy was solved by consultation with an investigator not involved in the initial procedure.

\section{Inclusion criteria}

1) Participants: COVID-19 patients of all ages (diagnostic criteria comply with WHO interim guidance [61]); 2) Outcomes: incidence of a history of cerebrovascular disease and (or) hypertension in patients with COVID-19, and (or) incidence of dizziness/headache as first symptoms; 3) Study design: published case series studies and observational studies.

\section{Exclusion criteria}

1) Absence of original data;2) sample size $<20$; 3) repeated publication of a study in different languages; 4 ) presence of selection bias, such as only including dead patients or critically ill patients etc.

\section{Quality assessment}

Using an assessment tool, two independent reviewers assessed the quality of the selected studies according to the recommendations of the United Kingdom National Institute for Health and Care Excellence (NICE) [62]. We analyzed the following eight domains: 1) cases are preferably come from medical institutions of different levels and perform multicenter research; 2) There are clear research hypothesis or purposes; 3) There are clear inclusion and exclusion criteria; 4) There are clear outcome indicators; 5) The data collected reach the expected goal; 6) patients are recruited continuously; 7) The authors clearly describe the study's primary findings; and 8) subgroup analysis and reporting of outcome indicators are performed. Studies are assigned one 
point for each criterion met, making the maximum score 8 points. Studies receiving $\geq 4$ points were considered to be of high methodological quality [62]. Any disagreement was resolved through discussion by the entire review team.

\section{Data extraction}

Two reviewers extracted data independently using a predefined data extraction form. Disagreements were resolved by discussion or consensus with a third reviewer. The data extracted included the first author; study characteristics (i.e., year and publishing language); participant characteristics (i.e., age, country, sample size); and outcomes (i.e., incidence of cerebrovascular diseases or hypertension as comorbidity or dizziness/headache as the first symptom in patients with COVID-19). Cerebrovascular diseases (ischemic and hemorrhagic cerebrovascular diseases) refers to transient or permanent neurological dysfunction caused by one or more cerebrovascular diseases arising for various reasons [63]. In addition, diagnoses of hypertension complied with the Japanese Society of Hypertension Guidelines [64]. For studies with insufficient information, the reviewers contacted the primary authors, when possible, to acquire and verify the data.

\section{Statistical analysis}

Constituent ratios were pooled using the mean and standard error (SE) values and were weighted using the inverse variance method [65]. We calculated $95 \%$ confidence intervals (CIs) using the Mantel-Haenszel statistical method. I-square $\left(\mathrm{I}^{2}\right)$ statistics and $\mathrm{Q}$ tests were performed to assess the impact of study heterogeneity on the results of the meta-analysis. According to the Cochrane review guidelines [66], if severe heterogeneity was present $\left(\mathrm{P}<0.1\right.$ or $\left.\mathrm{I}^{2}>50 \%\right)$, randomized effect models were chosen, otherwise fixed effect models were used. Subgroup analyses were performed based on the country, sex ratio, and sample size. To evaluate the quality and consistency of the results, a sensitivity analysis was conducted by removing individual studies. When the number of relevant studies was $\geq 10$, the publication bias test tool included with the RevMan 5.3 software package was applied, and the funnel plot was visually inspected to assess publication bias.

\section{Abbreviations}

SE: Standard error; CIs: Confidence interval(s); $\mathrm{I}^{2}$ : Isquare; RD: Ratio difference; ACE2: Angiotensinconverting enzyme 2; SARS-CoV-2: Severe Acute Respiratory Syndrome Coronavirus 2.

\section{AUTHOR CONTRIBUTIONS}

Jun Zhang, Haili Wang, Min Wei, and Hengzhu Zhang: gathered data, making of charts and figure, writing of the manuscript. Lun Dong, and Yuping Li: revising the manuscript, acquisition of data, accepts responsibility for conduct of research and final approval. All authors contributed to the interpretation of the data and to writing of the paper. All authors read and approved the final manuscript.

\section{CONFLICTS OF INTEREST}

The authors report no conflicts of interest in this work.

\section{FUNDING}

This study was supported by the Jiangsu Province Key Experiments of Basic and Clinical Translation of Noncoding RNA (201902); Jiangsu Province Natural Science Foundation (BK20190241); and Jiangsu Provincial Key Medical Talents Program (QNRC2016326).

\section{REFERENCES}

1. Zhang J, Wang $H$, Dong L. Letter to the editor: family member visits to critically ill patients during COVID-19: a new pathway. Telemed J E Health. 2020; 26:853-54. https://doi.org/10.1089/tmj.2020.0097 PMID:32315253

2. World Health Organization. Corona-virus disease (COVID-19) outbreak. https://www.who.int

3. Wang $H$, Tang $X$, Fan $H$, Luo $Y$, Song $Y, X u ~ Y$, Chen $Y$. Potential mechanisms of hemorrhagic stroke in elderly COVID-19 patients. Aging (Albany NY). 2020; 12:10022-34.

https://doi.org/10.18632/aging.103335 PMID: $\underline{32527987}$

4. Zhang J, Wang H, Li Y, Dong L. Letter to the editor "the battle of humans and COVID-19: a war without smoke". World Neurosurg. 2020; 139:714. https://doi.org/10.1016/j.wneu.2020.04.101 PMID:32353542

5. World Health Organization. Coronavirus disease 2019 (COVID-19) situation report-194. https://www. who.int/

6. Aggarwal G, Lippi G, Michael Henry B. Cerebrovascular disease is associated with an increased disease severity in patients with Coronavirus Disease 2019 (COVID-19): A pooled analysis of published literature. Int J Stroke. 2020; 15:385-389. https://doi.org/10.1177/1747493020921664 PMID:32310015 
7. Wang B, Li R, Lu Z, Huang Y. Does comorbidity increase the risk of patients with COVID-19: evidence from meta-analysis. Aging (Albany NY). 2020; 12:6049-57. https://doi.org/10.18632/aging.103000 PMID:32267833

8. Li D, Long YZ, Huang P, Guo WL, Wu SH, Zhou Q, Fu JL. [Clinical characteristics of 80 patients with COVID-19 in Zhuzhou City]. Chin J Infect Control. 2020; 19:227-233. https://doi.org/10.12138/i.issn.1671-9638.20206514

9. Yuan $Q$, Sun $Y Y$, Zuo YJ, Chen TY, Cao Q, Yuan GD, Yang M, Zhang W, Peng AZ, Chen YK. [Analysis 223 patients with COVID-19 of clinical characteristics in Chongqing]. J of Southwest Univ (Natural Science). 2020; 42:17-24. https://doi.org/10.13718/j.cnki.xdzk.2020.03.003

10. Wang K, Kang SR, Tian RH, Wang Y, Zhang XZ, Li HM. [CT characteristic appearances of patients with novel coronavirus pneumonia]. Chinese Journal of Clinical Medicine. 2020; 27:27-31.

https://doi.org/10.12025/j.issn.1008$\underline{6358.2020 .20200169}$

11. Zhang YM, Zhang X, Wu D, Chen X, Zhang L, Zhang DW. [Clinical characteristics of COVID-19 and related nursing care]. Acad J Chin PLA Med Sch. 2020; 41: 212-216. http://kns.cnki.net/kcms/detail/10.1117.r. 20200421.1845.011.html

12. Zuo FT, Li LC, Dong ZG, Chang XH, Jia MY, Wei CM, Zheng XS. [Analysis of thecorrelation between clinical characteristics and disease severity in patients with novel coronavirus pneumonia]. Tianjin Med J. 2020; 48:455-460. http://kns.cnki.net/kcms/detail/12.1116. r.20200413.1014.006.html

13. Wang R, Xie LL, Du P, Fan HQ, Song MY. [Clinical characteristics of 96 hospitalized patients with coronavirus disease 2019]. Chinese Journal of Respiratory and Critical Care Medicine. 2020; 19: 144-147.

https://doi.org/10.7507/1671-6205.202002066

14. Lei Y, Lu J, Gu JY, Zhou DF, Li YY, Lu QF. [Clinical features of 51 patients with corona virus disease 2019 in Wuhan City]. Journal of Shandong University (Health Sciences). 2020; 58:1-6. http://kns.cnki.net/kcms/ detail/37.1390.R.20200414.1315.006.html

15. Dong L, Yang SJ, Zhang LS, Zhang ZH, Wang RQ, Xu K, Liu JL. [A preliminary study on clinical characteristics and pathological characteristics of 27 cases of COVID19 patients in Sichuan]. Pharmacology and Clinics of Chinese Materia Medica. 2020; 2:50-53. https://doi.org/10.13412/j.cnki.zyyl.20200420.002.

16. Zhao L, Xue J, Wang YL, Dai EH, Xu ZG, Li YN, Dun ZQ, Gao HX, Rong YY, Chen C. [The clinical feature and imaging analysis of patients with new coronavirus infection in Shijiazhuang]. Tianjin Med J. 2020; 48:
513-517. http://kns.cnki.net/kcms/detail/12.1116.r. 20200417.1147.002.html

17. Tong GD, Xia Z, Wang YX, Chen S, Wu ZM, Zeng ZY, Deng $X$. [The clinical features of 258 cases of new coronavirus pneumonia in Shenzhen City]. Journal of Traditional Chinese Medicine. 2020. [Epub ahead of print]. http://kns.cnki.net/kcms/detail/11.2166.R. 20200413.1552.006.html.

18. Suo T, Wang YN, Zhao KC, Chen GZ. Clinical characteristics and outcome analysis of COVID-19 patients with chronic underlying diseases. Medical Journal of Wuhan University. 2020. [Epub ahead of print]. https://doi.org/10.14188/j.1671-8852.2020.0233.

19. Zhong SH, Lin F, Shi L. [The clinical characteristics and outcome of 62 patients with COVID-19]. Medical Journal of Chinese People's Liberation Army. 2020. [Epub ahead of print]. http://kns.cnki.net/kcms/ detail/11.1056.R.20200326.1308.002.html

20. Xu J, Han MF, Zhao FD, Zhang T, Ma L. [Clinical manifestation sandsero-immunological characteristics of 155 patients with COVID-19]. Chin J Nosocomio. 2020; 30:961-965. https://doi.org/10.11816/cn.ni.2020-200577

21. Gong XY, Wei DR, Gong X, Xiong Y, Wang T, Mou FZ. [Analysis on TCM Clinical Characteristics and Syndromes of 80 Patients with Novel Coronavirus Pneumonia]. Chinese Journal of Information on TCM. 2020; 27:1-6. http://kns.cnki.net/kcms/detail/11.3519. r.20200330.1553.002.html

22. Chen L, Yang XP, Zhen NH, Cai T, Hu YR, Gu JN, Zhao WH. [Clinical characteristics of 67 discharged cases of Corona Virus Disease 2019]. Chin J Nosocomiol. 2020; 30:801-805.

https://doi.org/10.11816/cn.ni.2020-200526

23. Lu YF, Yang ZG, Wang $M$, Shi J, Wang ZW, Lv Y, Tang BZ, Ye C, Xu QN, Yin KS, Chen XR. [Analysis on Chinese medical clinical characteristics of 50 patients with novel coronavirus-infected pneumonia]. Academic Journal of Shanghai University of Traditional Chinese Medicine. 2020; 34:17-21. https://doi.org/10.16306/j.1008-861x.2020.02.003

24. Huang XQ, Nie LH, Li FM, Wang C, Chen G, Cai KK, Yu CY, Li C. [Analysis of Chinese Medical Characteristics of 35 Patients with Novel Coronavirus Pneumonia]. JETCM. 2020; 29:381-383. https://doi.org/10.3969/j.issn.1004-745X.2020.03.002

25. Liang YL, Yue F, Song L. [Epidemiological and Clinical Characteristics of 28 Confirmed Cases of Novel Coronavirus Pneumonia]. Clinical Research. 2020; 28:1-3. http://www.wanfangdata.com.cn/details/detail. do? type=perio\&id=yyybj202004001 
26. Zhuang YJ, Chen Z, Li J, Yang XL, Li J, Yuan Y, Guan Q, Jia HJ, Ma QY, Wu D, Ma HB, Tang ZR. [Clinical and epidemiological characteristics of 26 patients diagnosed with COVID-19]. Chin J Nosocomiol. 2020; 30:826-829.

https://doi.org/10.11816/cn.ni.2020-200207

27. Yang $W$, Cao $Q$, Qin L, Wang $X$, Cheng Z, Pan A, Dai J, Sun Q, Zhao F, Qu J, Yan F. Clinical characteristics and imaging manifestations of the 2019 novel coronavirus disease (COVID-19):A multicenter study in Wenzhou city, Zhejiang, China. J Infect. 2020; 80:388-93.

https://doi.org/10.1016/j.jinf.2020.02.016

PMID:32112884

28. Chen J, Qi T, Liu L, Ling Y, Qian Z, Li T, Li F, Xu Q, Zhang $Y$, $X u$ S, Song $Z$, Zeng $Y$, Shen $Y$, et al. Clinical progression of patients with COVID-19 in Shanghai, China. J Infect. 2020; 80:e1-e6.

https://doi.org/10.1016/i.jinf.2020.03.004

PMID:32171869

29. Liu K, Chen Y, Lin R, Han K. Clinical features of COVID19 in elderly patients: a comparison with young and middle-aged patients. J Infect. 2020; 80:e14-18.

https://doi.org/10.1016/i.jinf.2020.03.005 PMID:32171866

30. Lovell N, Maddocks M, Etkind SN, Taylor K, Carey I, Vora V, Marsh L, Higginson IJ, Prentice W, Edmonds P, Sleeman KE. Characteristics, symptom management, and outcomes of 101 patients with COVID-19 referred for hospital palliative care. J Pain Symptom Manage. 2020; 60:e77-81.

https://doi.org/10.1016/i.jpainsymman.2020.04.015 PMID:32325167

31. Huang $C$, Wang $Y$, Li $X$, Ren L, Zhao J, Hu Y, Zhang L, Fan G, Xu J, Gu X, Cheng Z, Yu T, Xia J, et al. Clinical features of patients infected with 2019 novel coronavirus in Wuhan, China. Lancet. 2020; 395:497-506. https://doi.org/10.1016/S0140-6736(20)30183-5 PMID:31986264

32. Chen $N$, Zhou $M$, Dong $X$, Qu J, Gong $F$, Han $Y$, Qiu $Y$, Wang J, Liu Y, Wei Y, Xia J, Yu T, Zhang X, Zhang L. Epidemiological and clinical characteristics of 99 cases of 2019 novel coronavirus pneumonia in Wuhan, China: a descriptive study. Lancet. 2020; 395:507-13. https://doi.org/10.1016/S0140-6736(20)30211-7 PMID:32007143

33. Zhou F, Yu T, Du R, Fan G, Liu Y, Liu Z, Xiang J, Wang Y, Song B, Gu X, Guan L, Wei Y, Li H, et al. Clinical course and risk factors for mortality of adult inpatients with COVID-19 in Wuhan, China: a retrospective cohort study. Lancet. 2020; 395:1054-1062.

https://doi.org/10.1016/S0140-6736(20)30566-3 PMID:32171076
34. Goyal P, Choi JJ, Pinheiro LC, Schenck EJ, Chen R, Jabri A, Satlin MJ, Campion TR Jr, Nahid M, Ringel JB, Hoffman KL, Alshak MN, Li HA, et al. Clinical characteristics of covid-19 in New York city. N Engl J Med. 2020; 382:2372-74.

https://doi.org/10.1056/NEJMc2010419 PMID: $\underline{32302078}$

35. Guan WJ, Ni ZY, Hu Y, Liang WH, Ou CQ, He JX, Liu L, Shan $\mathrm{H}$, Lei CL, Hui DS, Du B, Li L, Zeng G, et al, and China Medical Treatment Expert Group for Covid-19. Clinical characteristics of coronavirus disease 2019 in China. N Engl J Med. 2020; 382:1708-20. https://doi.org/10.1056/NEJMoa2002032 PMID: 32109013

36. Chen $T$, Dai $Z$, Mo P, Li X, Ma Z, Song $S$, Chen X, Luo M, Liang K, Gao S, Zhang Y, Deng L, Xiong Y. Clinical characteristics and outcomes of older patients with coronavirus disease 2019 (COVID-19) in Wuhan, China: a single-centered, retrospective study. J Gerontol A Biol Sci Med Sci. 2020; 75:1788-95.

https://doi.org/10.1093/gerona/glaa089 PMID: 32279081

37. Qian $G Q$, Yang NB, Ding $F$, Ma AH, Wang $Z Y$, Shen $Y F$, Shi CW, Lian X, Chu JG, Chen L, Wang ZY, Ren DW, Li GX, et al. Epidemiologic and clinical characteristics of 91 hospitalized patients with COVID-19 in Zhejiang, China: a retrospective, multi-centre case series. QJM. 2020; 113:474-81.

https://doi.org/10.1093/qjmed/hcaa089

PMID: $\underline{32181807}$

38. Liu K, Fang YY, Deng Y, Liu W, Wang MF, Ma JP, Xiao W, Wang YN, Zhong MH, Li CH, Li GC, Liu HG. Clinical characteristics of novel coronavirus cases in tertiary hospitals in Hubei Province. Chin Med J (Engl). 2020; 133:1025-31.

https://doi.org/10.1097/CM9.0000000000000744 PMID: $\underline{32044814}$

39. Zhang JJ, Dong X, Cao YY, Yuan YD, Yang YB, Yan YQ, Akdis CA, Gao YD. Clinical characteristics of 140 patients infected with SARS-CoV-2 in Wuhan, China. Allergy. 2020; 75:1730-41.

https://doi.org/10.1111/all.14238 PMID:32077115

40. Zhou Y, Han T, Chen J, Hou C, Hua L, He S, Guo Y, Zhang $S$, Wang Y, Yuan J, Zhao C, Zhang J, Jia Q, et al. Clinical and autoimmune characteristics of severe and critical cases of COVID-19. Clin Transl Sci. 2020; 10:1111. https://doi.org/10.1111/cts.12805 PMID:32315487

41. Xu XW, Wu XX, Jiang XG, Xu KJ, Ying $L$, Ma CL, Li SB, Wang HY, Zhang S, Gao HN, Sheng JF, Cai HL, Qiu YQ, Li $\sqcup$. Clinical findings in a group of patients infected with the 2019 novel coronavirus (SARS-cov-2) outside of Wuhan, China: retrospective case series. BMJ. 2020; 368:m606. 
https://doi.org/10.1136/bmj.m606

PMID:32075786

42. Chen T, Wu D, Chen H, Yan W, Yang D, Chen G, Ma K, Xu D, Yu H, Wang H, Wang T, Guo W, Chen J, et al. Clinical characteristics of 113 deceased patients with coronavirus disease 2019: retrospective study. BMJ. 2020; 368:m1091.

https://doi.org/10.1136/bmj.m1091 PMID:32217556

43. Zheng S, Fan J, Yu F, Feng B, Lou B, Zou Q, Xie G, Lin S, Wang $R$, Yang $X$, Chen W, Wang $Q$, Zhang $D$, et al. Viral load dynamics and disease severity in patients infected with SARS-CoV-2 in Zhejiang Province, China, JanuaryMarch 2020: retrospective cohort study. BMJ. 2020; 369:m1443.

https://doi.org/10.1136/bmj.m1443 PMID:32317267

44. Liang WH, Guan WJ, Li CC, Li YM, Liang HR, Zhao Y, Liu $X Q$, Sang L, Chen RC, Tang $C L$, Wang $T$, Wang $W$, He $\mathrm{QH}$, et al. Clinical characteristics and outcomes of hospitalised patients with COVID-19 treated in Hubei (epicentre) and outside Hubei (non-epicentre): a nationwide analysis of China. Eur Respir J. 2020; 55:2000562.

https://doi.org/10.1183/13993003.00562-2020

PMID:32269086

45. Wang D, Hu B, Hu C, Zhu F, Liu X, Zhang J, Wang B, Xiang $\mathrm{H}$, Cheng Z, Xiong $\mathrm{Y}$, Zhao $\mathrm{Y}$, Li $\mathrm{Y}$, Wang $\mathrm{X}$, Peng Z. Clinical characteristics of 138 hospitalized patients with 2019 novel coronavirus-infected pneumonia in Wuhan, China. JAMA. 2020; 323:1061-69. https://doi.org/10.1001/jama.2020.1585 PMID:32031570

46. Zheng $F$, Tang $W$, Li H, Huang YX, Xie YL, Zhou ZG. Clinical characteristics of 161 cases of corona virus disease 2019 (COVID-19) in Changsha. Eur Rev Med Pharmacol Sci. 2020; 24:3404-10.

https://doi.org/10.26355/eurrev 20200320711 PMID: $\underline{32271459}$

47. Wu J, Liu J, Zhao X, Liu C, Wang W, Wang D, Xu W, Zhang C, Yu J, Jiang B, Cao H, Li L. Clinical characteristics of imported cases of coronavirus disease 2019 (COVID-19) in Jiangsu Province: a multicenter descriptive study. Clin Infect Dis. 2020; 71:706-12. https://doi.org/10.1093/cid/ciaa199 PMID:32109279

48. Wang L, Duan Y, Zhang W, Liang J, Xu J, Zhang Y, Wu C, $\mathrm{Xu} \mathrm{Y,} \mathrm{Li} \mathrm{H.} \mathrm{Epidemiologic} \mathrm{and} \mathrm{clinical} \mathrm{characteristics} \mathrm{of}$ 26 cases of COVID-19 arising from patient-to-patient transmission in Liaocheng, China. Clin Epidemiol. 2020; 12:387-91.

https://doi.org/10.2147/CLEP.S249903

PMID:32308494

49. Grasselli G, Zangrillo A, Zanella A, Antonelli M, Cabrini L, Castelli A, Cereda D, Coluccello A, Foti G, Fumagalli R, lotti G, Latronico N, Lorini $\mathrm{L}$, et al, and COVID-19 Lombardy ICU Network. Baseline characteristics and outcomes of 1591 patients infected with SARS-CoV-2 admitted to ICUs of the Lombardy region, Italy. JAMA. 2020; 323:1574-81.

https://doi.org/10.1001/jama.2020.5394

PMID:32250385

50. Richardson S, Hirsch JS, Narasimhan M, Crawford JM, McGinn T, Davidson KW, Barnaby DP, Becker LB, Chelico JD, Cohen SL, Cookingham J, Coppa K, Diefenbach MA, et al, and the Northwell COVID-19 Research Consortium. Presenting characteristics, comorbidities, and outcomes among 5700 patients hospitalized with COVID-19 in the New York city area. JAMA. 2020; 323:2052-59. https://doi.org/10.1001/jama.2020.6775 PMID:32320003

51. Wan S, Xiang Y, Fang W, Zheng Y, Li B, Hu Y, Lang C, Huang $D$, Sun $Q$, Xiong $Y$, Huang $X$, Lv J, Luo $Y$, et al. Clinical features and treatment of COVID-19 patients in northeast Chongqing. J Med Virol. 2020; 92:797-806. https://doi.org/10.1002/imv.25783 PMID:32198776

52. Xu X, Yu C, Qu J, Zhang L, Jiang S, Huang D, Chen B, Zhang Z, Guan W, Ling Z, Jiang R, Hu T, Ding Y, et al. Imaging and clinical features of patients with 2019 novel coronavirus SARS-CoV-2. Eur J Nucl Med Mol Imaging. 2020; 47:1275-80.

https://doi.org/10.1007/s00259-020-04735-9 PMID: $\underline{32107577}$

53. Wang $X$, Fang J, Zhu Y, Chen L, Ding F, Zhou R, Ge L, Wang $F$, Chen $Q$, Zhang $Y$, Zhao Q. Clinical characteristics of non-critically ill patients with novel coronavirus infection (COVID-19) in a Fangcang Hospital. Clin Microbiol Infect. 2020; 26:1063-68. https://doi.org/10.1016/i.cmi.2020.03.032 PMID:32251842

54. Zhang X, Cai H, Hu J, Lian J, Gu J, Zhang S, Ye C, Lu Y, Jin C, Yu G, Jia H, Zhang Y, Sheng J, et al. Epidemiological, clinical characteristics of cases of SARS-CoV-2 infection with abnormal imaging findings. Int J Infect Dis. 2020; 94:81-87.

https://doi.org/10.1016/i.ijid.2020.03.040 PMID:32205284

55. Zhu J, Ji P, Pang J, Zhong Z, Li H, He C, Zhang J, Zhao C. Clinical characteristics of 3062 COVID-19 patients: a meta-analysis. J Med Virol. 2020; 10:1002. https://doi.org/10.1002/jmv.25884 PMID: $\underline{32293716}$

56. Meredith W, Jennifer CF, Jocelyn K, Catherine M. How does coronavirus kill? Clinicians trace a ferocious rampage through the body, from brain to toes. Science. 2020. https://doi.org/10.1126/science.abc3208 
57. Lambert DW, Clarke NE, Turner AJ. Not just angiotensinases: new roles for the angiotensinconverting enzymes. Cell Mol Life Sci. 2010; 67:89-98. https://doi.org/10.1007/s00018-009-0152-x PMID:19763395

58. Li Y, Li M, Wang M, Zhou Y, Chang J, Xian Y, Wang D, Mao L, Jin H, Hu B. Acute cerebrovascular disease following COVID-19: a single center, retrospective, observational study. Stroke Vasc Neurol. 2020. [Epub ahead of print]. https://doi.org/10.1136/svn-2020-000431 PMID:32616524

59. Divani AA, Liu X, Di Napoli M, Lattanzi S, Ziai W, James ML, Jafarli A, Jafari M, Saver JL, Hemphill JC, Vespa PM, Mayer SA, Petersen A. Blood Pressure Variability Predicts Poor In-Hospital Outcome in Spontaneous Intracerebral Hemorrhage. Stroke. 2019; 50:2023-2029. https://doi.org/10.1161/STROKEAHA.119.025514 PMID:31216966

60. Liberati A, Altman DG, Tetzlaff J, Mulrow C, Gøtzsche PC, loannidis JP, Clarke M, Devereaux PJ, Kleijnen J, Moher D. The PRISMA statement for reporting systematic reviews and meta-analyses of studies that evaluate health care interventions: explanation and elaboration. J Clin Epidemiol. 2009; 62:e1-34. https://doi.org/10.1016/i.jclinepi.2009.06.006 PMID:19631507

61. World Health Organization. Clinical management of severe acute respiratory infection when novel coronavirus (2019-nCoV) infection is suspected: interim guidance. 2020. https://apps.who.int/iris/ bitstream/handle/10665/330374/WHO-2019-nCoVlaboratory-2020.1-eng.pdf

62. NICE. Appendix 4 Quality of case series form [EB/OL] (2015-07-08) [2020-04-29]. http://www.nice.org.uk/ guidance/index

63. Chen $\mathrm{Y}, \mathrm{Hu} \mathrm{FY}, \mathrm{Wu}$ B. Interpretation of "Chinese classification of cerebrovascular diseases (2015)". Chin J Contemp Neurol Neurosurg. 2017; 17:865-868. https://doi.org/10.3969/j.issn.1672-6731.2017.12.002

64. Umemura S, Arima $\mathrm{H}$, Arima S, Asayama $\mathrm{K}$, Dohi $\mathrm{Y}$, Hirooka $Y$, Horio T, Hoshide S, Ikeda S, Ishimitsu T, Ito $M$, Ito $S$, Iwashima $Y$, et al. The Japanese society of hypertension guidelines for the management of hypertension (JSH 2019). Hypertens Res. 2019; 42:1235-481.

https://doi.org/10.1038/s41440-019-0284-9 PMID:31375757

65. Zhou XH, Obuchowski NA, McClish DK. Statistical methods in diagnostic medicine. New York. Wiley; 2002.

https://doi.org/10.1002/9780470317082

66. Higgins JPT, Green S. Cochrane Handbook for Systematic Reviews of Interventions Version 5.1.0 [updated March 2011]. The Cochrane Collaboration 2011. http://training.cochrane.org/handbook 